\title{
Między samotnością a solidarnością. Wokół problematyki podmiotowości w późnej krytyce literackiej Stanisława Barańczaka
}

W recenzji tomiku Obo Mirona Białoszewskiego Stanisław Barańczak zauważa, że „kartka” z jego wiersza - której napis głosił „ «Nie każcie mi już niczym więcej być!», niczym więcej niż tylko sobą" - ma też drugą stronę. Zgodnie z tezą interpretacyjną udowadnianą przez badacza „w równaniu «Ja a Inni» drugi człon jest opatrzony zarówno minusem, jak plusem, stanowi tak zagrożenie, jak i przyciagający magnes”. Kwestia ta - problem ambiwalentnej sytuacji człowieka zawieszonego między indywidualizmem a wspólnotowością - stanowi jeden z podstawowych problemów krytyki literackiej Barańczaka, nawet jeśli nie zawsze jest w niej obecna explicite. Autor Etyki $i$ poetyki przy różnych okazjach podejmuje próby unieważnienia dychotomii publiczne - prywatne. Znajduje to odzwierciedlenie przede wszystkim w jego retoryce krytycznej, w stylu czytania, w sposobie rozłożenia akcentów podczas zabiegów interpretacyjnych - jak chociażby w przywołanym wyimku z recenzji Białoszewskiego. Wiąże się to z Barańczaka specyficzną - wyczuloną na różnego rodzaju „paradoksy”, „ambiwalencje”, „, niuanse”, „antynomie” sytuacji człowieka współczesnego - wrażliwością pisarską.

Chciałabym przyjrzeć się funkcjonowaniu tego swoistego paradoksu tożsamości - tożsamości rozpiętej między samotnością a solidarnością ${ }^{\mathrm{I}}-\mathrm{w}$ jego tekstach krytycznych z lat 80 . i 90. i zastanowić się nad jego znaczeniem w ogólnej refleksji eseistycznej Barańczaka, która wciąż stanowi inspirujący teren w polskim krajobrazie intelektualnym minionych kilku dekad i nie daje się zamknąć jedynie w wąskich, doraźnych ramach krytyki poezji. Dlatego też przywołam nie tylko jego szkice kry-

I Solidarność $i$ samotność to tytuł wydanego pierwszy raz w 1986 r. nakładem „Zeszytów Literackich” zbioru esejów Adama Zagajewskiego, który użył tej formuły, by nazwać zasadniczy problem całego pokolenia ' 68 . 
tyczne, które lokalizują „problem tożsamości” w konkretnych, omawianych przez recenzenta tekstach i tomikach poetyckich, ale również inne jego wypowiedzi - w tym najważniejszy dla tego zagadnienia autobiografizujący esej O pisaniu wierszy. Pozwoli to, mam nadzieję, nakreślić szersze tło dla interesujących mnie tożsamościowych wątków spuścizny krytycznej autora $\mathrm{K} Q-$ rekty twarzy. Wątków, które pojawiają się w niej w formie luźnej, niesystematycznej i nie składają się na jakąś jedną, spójną, jasno wyartykułowaną koncepcję podmiotowości. Będę więc w moich rozważaniach bazować na trochę rozproszonym materiale - elementach refleksji autora Korekty twarzy, a także na wnioskach płynących z jego retoryki krytycznej i eseistycznej. W niczym nie umniejsza to jednak doniosłości podjętej tu problematyki, która jest jednym z najistotniejszych motywów twórczości krytycznej Barańczaka, organicznie związanym z innymi kluczowymi motywami, takimi jak poezja, „nieufność”, etyka.

\section{Paradoks tożsamości}

Tym, co uderza w przywołanym na początku komentarzu na temat poezji Białoszewskiego - a także w lekturze wielu innych recenzji Barańczaka z tomu Przed i po, który chciałabym uczynić przedmiotem mojej uwagi ${ }^{2}$ - jest niezgoda na jednostronność ujęcia problemu indywidualizmu oraz zaangażowania, podkreślanie dialektyczności tego zagadnienia, stałej rewersyjności, integralności dwóch stron jednego w gruncie rzeczy zjawiska. Ta niezgoda - silnie manifestowana zresztą również w wywiadach - na podporządkowanie człowieka tylko jednej z tych dwóch perspektyw, nie może przesłaniać faktu, że jego recenzje $\mathrm{z}$ lat 80 . zdominowane zostały przez retorykę, która odsłaniała i podkreślała przede wszystkim ową drugą stronę paradoksu, a więc społeczno-etyczny aspekt tożsamości człowieka. Nie jest to działanie neutralne $\mathrm{z}$ punktu widzenia realiów społecznych

2 Warto przywołać opinię Mariana Stali na temat tego tomu: „Skrótowość krytycznego wywodu, nieciągłość i fragmentaryczność obrazu współczesnej poezji, wynikające ze skupienia uwagi na wybranych dziełach i twórców, wreszcie: umieszczenie każdego z prezentowanych faktów w bliskim kontekście estetycznym i moralnym - mogłyby w sumie rodzić przekonanie, iż skonstruowana w ten sposób całość to zapis doraźnych, warunkowanych przez sytuację działań autora i że stanowi ona margines jego krytycznej twórczości [...]. Wyrazistość głosu Barańczaka, wyczuwalna w eseistyce równie mocno jak w poezji, oraz spoistość głoszonego przezeń systemu wartości nadają jednak książce sporą wagę”. M. Stala, Ironia i wierność, w: Przeszukiwanie czasu. Przechadzki krytycznoliterackie, Kraków 2004. s. 200. 
tamtego czasu i funkcjonujących wtedy ruchów opozycyjnych wobec niedemokratycznych władz w Polsce. Kontekst polityczny, który dominuje zwłaszcza w drugiej części tomu Przed i po - powstałej już po wprowadzeniu stanu wojennego w Polsce - nie eliminuje jednak kontekstu egzystencjalnego, jaki otwiera teza o dwoistej naturze tożsamości człowieka. W istocie tylko ten kontekst stanowi przedmiot mojego zainteresowania. Interpretacje i refleksje Barańczaka ze wspomnianego tu okresu można odczytywać, zakładając przewagę znaczenia pragmatycznego, a Przed $i$ po nie jest aż tak zdeterminowaną przez okoliczności powstania książką, jak na pierwszy rzut oka mogłoby się wydawać. Zawarte w niej analizy poszczególnych tomów poezji są oczywiście zawsze czymś więcej niż tylko ilustracjami tezy o przenikaniu się sfery prywatnej z publiczną, jednak uderzająca jest pewna cyrkularność, cechująca ten akurat tom cyrkularność, która przejawia się w ciągłym powracaniu do „paradoksu solidarności”, powracaniu przy okazji omawiania różnych zupełnie zbiorów, autorstwa różnych zupełnie poetów, których drogi twórcze nierzadko były od siebie radykalnie oddalone.

Spróbujmy zastanowić się nad tym, co osiąga krytyk przez takie a nie inne opisanie ich „miejsca wspólnego”, jakie wnioski płyną stąd dla jego nieustannie ponawianego postulatu powiązania poezji zżyciem. Okazuje się, że ramy konstrukcyjne większości jego recenzji przyjmują zwykle - zewnętrznie - jeden i ten sam kształt. Jest to mianowicie najczęściej swoista „rama paradoksu”, która nie jest dla Barańczaka sposobu myślenia o jednostce obojętna. Paradoks tożsamości byłby jednym $\mathrm{z}$ istotnych lejtmotywów tej krytyki, który nie jest już tylko odpowiedzią na dany tekst, ale odsyła do określonej wizji człowieka i świata. Wizji będącej już bardziej własnością systemu myślowego samego Barańczaka niż sumą idei komentowanych tomików poetyckich, wizji, która rodzi się z ich spotkania, powstaje na skutek - mówiąc językiem Hansa-Georga Gadamera - „fuzji horyzontów”. Z konieczności moje uwagi będą prowadziły do skatalogowania zasadniczych momentów występowania tego paradoksu na przestrzeni różnych wypowiedzi Barańczaka i do próby zrozumienia ich funkcji w ogólnym systemie wartości autora Etyki i poetyki.

Zacznijmy od części zatytułowanej Przed, gdzie problem ten zarysowuje się tylko trzykrotnie, jakby trochę z boku, i nie jest tak jawnie uwikłany politycznie jak w części Po. Pierwszy raz pojawia się w szkicu o Annie Kamieńskiej, oczywiście pod postacią paradoksu, który wynika - zdaniem Barańczaka - ze zderzenia „tonu etyczno-społecznego” jej poezji z opisywanym 
jednocześnie „intymno-prywatnym doświadczeniem”. 3 tej samej części książki mamy także recenzję tomiku Krzysztofa Karaska: „już tytuł tomu [Prywatna bistoria ludzkości] stapia w jedną całość historię jednostkową, osobistą, "prywatną" i historię powszechną, zbiorową, historię «ludzkości»" 4 , a najciekawsze wiersze to według krytyka te, które łączą obie perspektywy. Sygnalizowanym już wcześniej przypadkiem jest też omówienie zbioru Mirona Białoszewskiego, u którego „paradoksem solidarności” jest podstawowa „dialektyka stosunku «ja a inni»" i wartości tej poezji, stanowiąc osobny problem w historii poezji polskiej. Rzecz ciekawa: w omówieniach różnych tomików tego poety widać pewne przesunięcie punktu ciężkości, które następuje w części Po. Jest tak chyba dlatego, że cechuje się ona już zdecydowanie większą wyrazistością sądów - także sądów, które mogą być interpretowane w kontekście pragmatycznym. We wczesnym komentarzu do tomu Odczepić się ingerencja świata zewnętrznego jest stosunkowo ostrożnie określana jako „zarazem niepożądana - i nieunikniona”, a bohater Białoszewskiego, ze swoją „skłonnością do pustelniczej izolacji i indywidualistycznego widzenia rzeczywistości”, jest tylko „obserwatorem zewnętrznego, realnego świata" ${ }^{6}$. Z kolei w recenzji zbiorku Obo z 1985 r. - pisanej już na emigracji, umieszczonej w drugiej części Przed i po - retoryka Barańczaka prowadzi do nieco innego, charakterystycznego przeakcentowania problemu. Paradoks tożsamości zasadza się tutaj na tym, że właśnie „najbardziej prywatny $\mathrm{z}$ poetów napisal jeden $\mathrm{z}$ najbardziej realistycznych utworów literackich o stanie wojennym w Polsce" " , sama konstatacja natomiast jest pójściem o krok dalej. Podmiot utworu traktującego o tak doniosłym dla określonej zbiorowości wydarzeniu chodzi o Kabaret Kici Koci - nie jest już tylko „pełnoprawnym uczestnikiem", staje się aktywnym interpretatorem, wręcz kontestatorem. Krótka analiza owego tekstu prowadzi autora Jezzyka poetyckiego Mirona Białoszerwskiego do radykalniejszych niż wcześniej wniosków: „W istocie [...] jego przełomowa rola w literaturze polegała [...] na pokazaniu, że zazdrośnie strzeżona odrębność Ja wobec Wszystkiego Innego nie stoi na przeszkodzie całkowitemu otwarciu się na rzeczywistość" ${ }^{8}$. Głębszy, impliko-

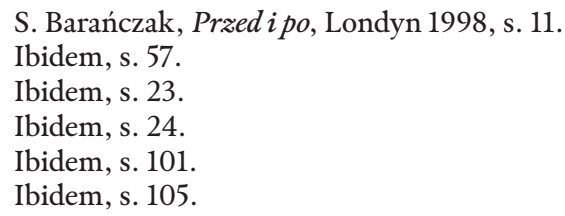


wany sens paradoksu polegałby więc na trudnej akceptacji tego, że tożsamość człowieka konstytuowana jest również przez otoczenie, świat zewnętrzny, innych ludzi, wobec których mamy określone zobowiązania.

Konsekwencje tego paradoksu są u Barańczaka oczywiście etyczne i nie mogą być inne, jeśli pamiętamy o najważniejszych założeniach jego szeroko zakrojonego projektu pisarskiego i egzystencjalnego - opartego na kategorii „nieufności”. Właśnie przede wszystkim w perspektywie moralnej należałoby rozumieć te użycia figury paradoksu, o których mowa. Taki punkt widzenia dominuje $\mathrm{w}$ większości recenzji z drugiej części tomu, choć pojawia się on w różnych szkicach pod różnymi postaciami - zaskakująco jednak zbieżnymi. Mamy więc różne językowe warianty na określenie tego samego paradoksu. Oczywiście, w jego użyciu pobrzmiewa echo pogrudniowej sytuacji społecznej w Polsce, ale - jak już podkreślałam - jego zasięg jest ogólniejszy. Zbierzmy więc najistotniejsze tezy tych szkiców z części Po, które operują antynomią prywatne - publiczne i scalają tę opozycję w jedną prawdę „paradoksu solidarności”. Zatem: u Wisławy Szymborskiej ,jak w każdym wybitnym dziele literackim naszej epoki spotykamy się [...] z sytuacją, w której poeta broni interesów ludzkiej społeczności właśnie przez obronę interesów jednostki" "; o sile poezji Wiktora Woroszylskiego przesądza zaś obecna w niej „dialektyka uczestnictwa i odstępstwa” " czeniu twórczości Adama Zagajewskiego decyduje to, że „nawet gdy pisze o sprawach publicznych, czyni je składnikiem prywatnego świata” "I w tekstach Piotra Sommera „wytwarzająca się dyskretnie wspólnota likwiduje osamotnienie bohatera" ${ }^{{ }_{2}}$; Jan Polkowski, choć jest "poetą historii i spraw publicznych”, to jednak światem twórczości pozostaje jednocześnie „świat pojedynczego człowieka" ${ }^{\text {33. }}$

Przywołane tezy interpretacyjne szkiców na temat tomików powstałych w cieniu rzeczywistości PRL-owskiej nie wyczerpują jednak tematu. Echa tego przekonania można znaleźć i w innych książkach krytycznych Barańczaka pisanych w latach 80., chociażby w zbiorze esejów Tablica z Macondo. Osiemnaście prób wythmaczenia, po co i dlaczego się pisze. Przywołajmy więc kolejne przykłady funkcjonowania interesującej nas kwestii. Jedną z manifestacji znajdujemy w szkicu z 1988 r. na temat zbioru li-

\footnotetext{
9 Ibidem, s. 114.

то Ibidem, s. 130 .

II Ibidem, s. 144.

I2 Ibidem, s. 157.

I3 Ibidem, s. 167.
} 
stów, rysunków i esejów Brunona Schulza. Autor Przed i posięga w nim po tę samą figurę paradoksu tożsamości - tożsamości człowieka, na którą składa się aspekt nie tylko indywidualny, ale i wspólnotowy. Formułuje w nim opinię, wedle której „w całkowitej sprzeczności z masochistycznym autoportretem Schulza, utrwalonym w obrazie i słowie, większość listów ukazuje go także jako człowieka, który $\mathrm{z}$ determinacją ponawia uporczywe wysiłki wydostania się z zaklętego kręgu upokorzenia i izolacji” ${ }^{\mathrm{I}}$. Już w tytule zawarty jest koncept, na którym opiera się cały tekst. Tytułowa Trwarz Brunona Schulza to bowiem symbol paradoksalnej, dwoistej osobowości pisarza. Zgodnie z wykładnią krytyka - który wychodzi od dosłownego znaczenia twarzy jako elementu jego autoportretów - twarz w sensie symbolicznym zawiera w sobie zarówno jego masochistyczny wizerunek, obecny w zbiorowej świadomości odbiorców, jak i „mniej znaną twarz” Schulza, który „jako artysta - nie miał sobie równych w nieustępliwości” ${ }^{15}$. Zacytujmy:

Po jednej stronie zatem - ściągnięta bólem twarz wyłaniająca się z fotografii, rysunków i listów, tych listów, w których przez nieśmiałość i powściągliwość przebijają się rozpaczliwe wołania o pomoc [...]. Po drugiej stronie - twarz człowieka, który o tejże samotności pisze [...]: „Samotność jest odczynnikiem [...], doprowadzającym rzeczywistość do fermentacji, do strącenia osadu figur i kolorów" ${ }^{\text {⒍ }}$.

Barańczak dochodzi do tej konkluzji przez wnikliwą analizę rysunków i grafik Schulza, a także jego listów, które - jako gatunek z definicji nakierowany na adresata, drugą osobę, kontakt $\mathrm{z}$ innymi ludźmi - tym bardziej skłaniają ku określonym wnioskom, uprawomocniając jego tezę. Nie sposób przy okazji nie zauważyć, że esej o Schulzu jest próbą przełamania dominującego stereotypu odbioru tej twórczości. Figura paradoksu stanowi tu swoisty oręż w walce przeciwko ogólnikowemu językowi, utartym formułom, spetryfikowanym wzorcom czytania. Sam szkic, którego kompozycja opiera się na synekdosze, stoi w wyraźnej opozycji do obiegowego wizerunku Schulza, dąży do jego skomplikowania. Znów chodzi jednak przede wszystkim o takie skomplikowanie, które odsłania społeczną stronę toż-

${ }^{4} 4$ S. Barańczak, Trwarz Brunona Schulza, w: Tablica z Macondo. Osiemnaście prób wythumaczenia, po co i dlaczego się pisze, Londyn 1990, s. 115.

5 Ibidem, s. 119.

${ }^{16}$ Ibidem. 
samości człowieka, nie pozwala zamknąć go w ściśle prywatnej perspektywie.

Jak mogliśmy zaobserwować, wszystkie zniuansowane w twórczości różnych pisarzy problemy Barańczak konsekwentnie opisuje za pomocą paradoksu - słowa klucza, którym nie operuje jednak tylko ze względu na jego retoryczne, dynamizujące wypowiedź właściwości, ale z uwagi na głęboki sens, jaki ten trop w tym kontekście artykułuje. Sens ów może stanowić wyjście z pułapki pozornie nieusuwalnej granicy między sferą prywatną a publiczną; pozwala wyobrazić sobie ideę solidarności, wspólnotowości powstałej na kanwie pojedynczych losów, ideę, która - nawiasem mówiąc - stanowi istotny problem współczesnej filozofii polityki. Jeśli przypomnimy sobie słownikową definicję paradoksu - figury, która ustala stosunek wzajemnego zawierania się różnych całości znaczeniowych - to okaże się, że za pomocą jednego tropu Barańczak łączy w spójną całość dwie skrajnie różne perspektywy filozoficzne: perspektywę indywidualistyczną i perspektywę wspólnotową. Na kartach jego recenzji spojrzenia te - chociaż zasadniczo skonfliktowane spotykają się i nie stanowią pary przeciwieństw.

Nasuwają się już pewne wnioski dotyczące głębszego sensu tego uprzywilejowania paradoksu tożsamości w krytyce Barańczaka. Jest to oczywiście pewna manifestacja jego przekonań światopoglądowych, które wyłuszczone zostały najpełniej w manifeście Tablica z Macondo albo: Najkrótsza poetyka normatyrena na użytek własny, w sześciu literach bez znaków diakrytycznych, $z$ dygresjami motoryzacyjno-metafizycznymi. Zarówno $\mathrm{w}$ nim, jak i w wywiadach autor Etyki i poetyki konsekwentnie buduje obraz jednostki usytuowanej wobec czegoś od niej większego i mającej pewne zobowiązania - między innymi wobec ludzi. Wydaje się, że taka perspektywa wiąże się jednakowo z jego antynomicznym i w pewnym sensie religijnym widzeniem miejsca człowieka w rzeczywistości i „metafizyczną” wyobraźnią - Barańczak tłumaczył przecież angielską poezję religijną baroku jak i z jego romantycznym światopoglądem, zgodnie z którym indywidualizm jest zawsze punktem wyjścia do zaangażowania w sprawy zbiorowości. Ten lejtmotyw twórczości autora Uciekiniera z Utopii i jego przejawy widoczne w postawie artystycznej pozornie potwierdzają konieczność czytania Barańczaka przez pryzmat politycznych doświadczeń. I faktycznie, w wielu wywiadach thumaczy on przyjęte przez siebie rozumienie powinności jednostki daną sytuacją historyczną, jak wtedy, gdy zauważa, że „wszystko w tych latach, co składało się na pojedyncze, prywatne, własne życie $[. .$.$] było [...] tak czy inaczej uwikłane w to,$ 
co działo się na zewnątrz jednostki, w dziejącą się historię, w perypetie całego społeczeństwa" ${ }^{17}$.

A jednak uwikłanie jednostki w to, co znajduje się poza nią, ma zdaniem Barańczaka wymiar szerszy i jest ugruntowane w samych już pojęciach tożsamości, jednostkowości, autonomii. Zacytujmy krótko kilka ważniejszych fragmentów. W Tablicy z Macondo... pisze, zainspirowany omawianymi przez niego listami Václava Havla: „sama tożsamość, ustanowiona poprzez poczucie odpowiedzialności, stawia człowieka po stronie "porządku Bytu», a przeciw "porządkowi śmierci» albo Nicości” ${ }^{\text {I8 }}$. W komentarzu na temat eseistyki Josifa Brodskiego wydobywa kategorię „etyka języka” i mówiąc o jej paradoksalnych podstawach, stwierdza: „pojęcie autonomii jednostkowej egzystencji to wartość ponadjednostkowa; więcej, to "podstawa naszej cywilizacji»" I9. W wywiadach oznajmia jednoznacznie: „każdy z nas jest jednocześnie solidarny z innymi i samotny [...]. Człowiek jako taki jest rozpięty między biegunami wspólnoty i obcości, solidarności i samotności - i właśnie to rozpięcie czy zawieszenie stanowi o jego człowieczeństwie" ${ }^{20}$.

\section{Między nieufnością a zaufaniem}

Zrekonstruowany wyżej - w stopniu minimalnym - styl myślenia Barańczaka o jednostce, choć związany źródłowo z konkretną sytuacją w czasach PRL-u, wpisywałby się interesująco w nowoczesny projekt szeroko rozumianej „romantyzacji”.

Romantyk - pisze jego „rzeczniczka” Agata Bielik-Robson - nie przekreśla wcale jednostkowej autonomii, lecz jedynie domaga się radykalnej zmiany jej definicji. Chce na powrót powiązać podmiot $\mathrm{z}$ jego światem, tradycją i wspólnotą. [...] Zarazem jednak nie chce poddać jej na powrót panowaniu sztywnych ponadjednostkowych praw $^{2 \mathrm{I}}$.

Pod tymi słowami z pewnością mógłby podpisać się Barańczak, którego twórczość - jak i całego pokolenia '68 - od-

I7 S. Barańczak, „Jestem pięknoduchem, estetą i parnasista”, w: Zaufać nieufności. Osiem rozmów o sensie poezji 1990-1992, red. K. Biedrzycki, Kraków 1993, s. 14.

I8 S. Barańczak, Horyzont absolutny, w: Tablica z Macondo..., s. 130.

I9 S. Barańczak, Rym i czas, w: ibidem, s. 136.

2. S. Barańczak, Autonomia i oparcie, w: Zaufać nieufności..., s. 48.

${ }^{2 I}$ A. Bielik-Robson, Inna nowoczesność. Pytania o wespótczesna formułe duchowości, Kraków 2000, s. 321. 
czytywana jest, jak wiadomo, przez pryzmat romantycznej tradycji. Zauważmy, że w jednym $\mathrm{z}$ wywiadów formułuje on podobną myśl. Mówiąc o wspólnych filozoficznych podstawach programowych książek poetów pokolenia '68 (Nieufni i zadufani samego Barańczaka oraz Świat nieprzedstawiony Adama $\mathrm{Za}-$ gajewskiego i Juliana Kornhausera) mówi mianowicie o tym, że „tylko ten może skutecznie wypowiadać protest przeciw światu, kto zasadniczo przyjmuje ten świat jako swój, nie wypiera się go ani go nie odrzuca, stawia siebie samego nie $\mathrm{z}$ boku, ale w obrębie tego świata" ${ }^{22}$. Nie chodziłoby więc w owym projekcie odpowiedzialnego uczestnictwa w społeczeństwie tylko o niezgodę na "upadek człowieka publicznego" ${ }^{23}$, ale - szerzej także o przyjęcie postawy afirmatywnej w stosunku do świata jako takiego. W innym wywiadzie Barańczak nazywa tę postawę „wewnętrzną uczciwością”, stwierdzając: „jeśli rzeczywiście nie godzimy się na świat in toto, jedynym wyjściem pozostaje samobójstwo" ${ }^{24}$. Redefinicja pojęcia autonomii, o której pisze Bielik- Robson, wiązałaby się z koniecznością uwzględnienia kategorii elementarnego „zaangażowania”, uwzględnienia zobowiązań jednostki, o których krytyk niejednokrotnie przy różnych okazjach przypomina, często za pomocą figury paradoksu.

Świadomość uwikłania $\mathrm{w}$ to, co publiczne, wspólnotowe, solidarne, świadomość konieczności zaangażowania się w otaczającą rzeczywistość otwiera na zaufanie w stosunku do języka. W perspektywie rozważań widać teraz, że „nieufność” - podstawowa kategoria systemu etycznego Barańczaka - jest bardziej skomplikowana i uwikłana w swoje dokładne przeciwieństwo, a więc radykalną afirmację świata, niż mogłoby to z pozoru wyglądać. Rzecz chyba tutaj najistotniejsza: to właśnie w języku poeta-krytyk widzi płaszczyznę, która umożliwia poezji posiadanie jakiegokolwiek znaczenia - znaczenia, które jednak już w żaden sposób nie może być zredukowane do kwestii językowych, znaczenia przede wszystkim moralnego i egzystencjalnego. O swojej najważniejszej emigracyjnej książce krytycznej Tablica z Macondo... powie w jednym $\mathrm{z}$ wywiadów, że jest to

zbiór wariacji na ten sam temat: jak jest możliwy ten zadziwiający paradoks poezji, polegający na tym, że to, co w niej najbardziej poetyckie, bynajmniej nie zamyka nas w wąskim wewnętrznym świe-

${ }^{22}$ S. Barańczak, „Jestem pięknoduchem, esteta i parnasista”, s. 23.

23 Sformułowanie Richarda Sennetta - zob. R. Sennett, Upadek człowieka publicznego, przeł. H. Janowska, Warszawa 2009.

${ }_{24}^{4}$ S. Barańczak, „Poezja musi być wieczna czujnościa”, w: Zaufać nieufności..., s. 60 . 
cie wiersza, ale właśnie pozwala nam lepiej zrozumieć zewnętrzny świat, skuteczniej się z nim borykać ${ }^{25}$.

Krótki esej Barańczaka O pisaniu wierszy daje impuls do refleksji nad granicami ,nieufności”, pozwala usytuować paradoks tożsamości w rozleglejszym krajobrazie myślowym autora Korekty twarzy, otworzyć jego wizję jednostki na szersze konteksty, dlatego też na owym paradoksie chciałabym skoncentrować teraz uwagę. Co ciekawe, wiele istotnych dla zagadnienia sensów wyraża już sama retoryka eseju, w której domyślnie zawarte jest dopełnienie i w pewnym sensie realizacja tego, co w tekście formułowane jest wprost. Pozwala to domniemywać, że Barańczaka aksjomat o głębokim potencjale sensotwórczym tkwiącym w języku poezji można by przenieść na grunt języka prozy eseistycznej. Tekst daje się interpretować również przez pryzmat szerszych zagadnień, niż sugeruje to tytuł (wyjątkowo nie metaforyczny, ale bardzo prosty $\left.{ }^{26}\right)$. Stanowi on polską wersję wstępu do wyboru własnych wierszy Barańczaka w przekładach na język angielski - The Weight Of The Body, wydanego w 1989 r. w Chicago - a osobisty kontekst powstania tomu nie pozostał bez wpływu na ton wypowiedzi. Ten zaledwie kilkustronicowy szkic nieprzypadkowo też, powiedzmy od razu, napisany został prostym, przejrzystym językiem. Pozornie koncentrując się tylko na sprawach wewnątrzpoetyckich, po kilku przesunięciach terminologicznych może on okazać się istotnym źródłem wiedzy na temat podstaw światopoglądowych Barańczaka i - przede wszystkim - na temat jego wizji podmiotu. Barańczak pisze w tymże eseju wprost, że jego własne wiersze - w domyśle: wszelkie jego twórcze wysiłki, realizowane nie tylko w poezji „wynikają tak z poczucia ludzkiej solidarności, jak i z doznania ludzkiej samotności”. Wyjściowa teza stanowi asumpt do rozważań, które wykraczają daleko poza czysto prywatny kontekst. Podstawowa refleksja jest nieskomplikowana: człowiek posiada głębokie możliwości językowego, a co za tym idzie, i egzystencjalnego przeciwstawienia się „pozorom zamętu i przypadku”. Możliwości te oferuje przede wszystkim, rzecz jasna, język poezji, któremu Barańczak zawsze wyznacza szczególną rolę. Esej O pisaniu wierszy stanowi w tym aspekcie po prostu kolejny wyraz jego ogólnej teorii związanej z rolą poezji, wyłożonej w wie-

25 S. Barańczak, Z trzech stron barykady, w: ibidem, s. 105.

${ }^{26}$ Co ciekawe, tytuł oryginalny brzmiał Playing It Straight - co zdecydowanie bardziej niż polska wersja współgra zarówno z dyskursywną, jak i pozadyskursywną treścią eseju. Można by oddać ten angielski idiom w postaci polskiego frazeologizmu „nie owijać w bawełnę”. 
lu esejach programowych i wyłaniającej się właściwie z każdego jego tekstu krytycznego, każdorazowo inaczej sformułowanej. Tutaj podkreślona zostaje funkcja „zdzierania” pozorów jednoznacznej chaotyczności świata, a także funkcja stabilizacji doświadczeń człowieka współczesnego, którego krytyk po raz kolejny sytuuje między różnymi biegunami - a stąd niedaleko już do rozważań wychodzących poza ramy teorii poezji.

Tekst zogniskowany jest wokół dwóch konkurencyjnych wobec siebie metafor, które można zinterpretować jako dwie różne wizje kondycji ludzkiej - mówiąc językiem filozofii. „Walka” między tymi metaforami jest właściwie streszczeniem „walki” nieufności z zaufaniem wobec języka, które to dwie postawy ścierają się $\mathrm{w}$ systemie myślowym Barańczaka. Obraz podmio$\mathrm{tu}^{27}$, jaki wyłania się z tego wstępu, pozornie jest wyciągnięciem ostatecznych konsekwencji z zasady „nieufności” - słowa klucza krytyki literackiej, poezji i w ogóle refleksji autora Nieufnych $i z a d u f a n y c h$ (gdyby pojmować ją w kategoriach kontrastu nie tylko etycznego, ale i egzystencjalnego). Pozornie to właśnie „doznanie samotności" - i między innymi w związku z tym przyjęcie „nieufnej” postawy - dominuje w całym jego doświadczaniu świata. Zacytujmy długi, znany fragment, w którym pojawia się pierwsza z podstawowych dla naszych rozważań metafor:

Bierze się ona [twórczość poetycka Barańczaka] cała $\mathrm{z}$ instynktownego przeświadczenia - tyleż silnego, co w oczywisty sposób pozbawionego racjonalnych podstaw - że większość z tego, co nas spotyka, jest pogwałceniem jakiejś niepisanej umowy, której istnienie dano nam aluzyjnie do zrozumienia $\mathrm{w}$ momencie narodzin. Rzucani nieznaną ręką $\mathrm{w}$ świat, mamy przecież - zdawałoby się prawo oczekiwać, że miejsce, w które nas się rzuca - jest przeznaczoną dla nas siedzibą, przestrzenią przychylną ludzkiemu życiu. Tymczasem wystarczy, że ufnie naciśniemy klamkę - jak lokator, wkraczający $\mathrm{w}$ progi mieszkania i pragnący jedynie spędzić parę chwil w spokoju - aby rozbłysły światła i ogłuszył nas krzyk zaczajonych po kątach gości urodzinowych: „NIESPODZIANKA!!!”. Nikt z nas "nigdy by nie przypuścił”, że od pierwszego momentu życia świat obejmie go uściskiem jednocześnie zachłannym i dławiącym, że rozciągnie go między biegunami rozkoszy i bólu, postawi go w swoim centrum i zarazem będzie nieustannie deptać jego godność, stanie mu się dobroczyńcą i prześladowcą w jednej postaci.

${ }_{27}$ Celowo używam w moich rozważaniach określenia „podmiot”, gdyż sądzę, że warto podejmować tego typu próby ogólniejszej, filozoficznej interpretacji krytyki Barańczaka, licząc się z dużym brakiem precyzji wniosków. 
„I nikt nas nie uprzedził”, że nasza umowa w sprawie wynajmu tego mieszkania, jakim jest życie, ma u spodu parę dodatkowych, drobnym drukiem wypisanych paragrafów - tych, które stwierdzają, że lokator ma obowiązek przyjąć lokal z całym wątpliwym dobrodziejstwem inwentarza: cierpieniem, samotnością, śmiercią ${ }^{28}$.

Łatwo jest dać zwieść się temu - wyjątkowo charakterystycznemu dla stylu, wyobraźni, dynamiki, typu refleksji krytycznej Barańczaka - ustępowi i uznać, że wprowadza on jedynie, jak pisze Jerzy Kandziora, „mroczny determinizm o niezwykłym stężeniu” i „wizję człowieka jako istoty bezwzględnie poddanej przymusom egzystencjalnym" ${ }^{29}$. Faktycznie, obraz podmiotu, jaki dostarcza nam szczególnie jeden sugestywny, niejednokrotnie cytowany wyimek z eseju O pisaniu wierszy, pozornie wpisywałby się bez reszty w wizję jednostki, jaką przynosi „nihilizm nieufności” - tak Bielik-Robson w książce Inna nowoczesność nazywa postawę, o której mniej więcej tu mowa. Jego istota wiązałaby się z podstawowym faktem - mianowicie tym, że

współczesność - jak pisze filozofka - jest epoką pogłębiającej się niepewności ontologicznej: braku elementarnego zaufania dla świata jako wyjątkowo nieprzyjaznego miejsca pobytu - i dla siebie jako istoty niewythumaczalnie skazanej na kondycję wrzucenia, bycia zależnym od czegoś, czemu ufać nie sposób ${ }^{3 \circ}$.

Barańczak przekłada tę podstawową filozoficzną metaforę „wrzucenia w świat” ${ }^{\text {I }}$ na własny - właściwie bardziej poetycki niż eseistyczny ${ }^{32}$ - język i, jak zobaczymy, wyciąga z niej wszelkie możliwie - również retoryczne - konsekwencje. Tak powstał jeden z bardziej sugestywnych obrazów krytycznych autora Etyki i poetyki, który rozpoczyna od wyjaśnienia źródeł własnej twórczości, by prędko przejść w plastyczny rysunek, przedstawiający najbardziej ogólną sytuację egzystencjalną człowieka. Fragment jest jasnym sygnałem filozoficznych i totalizujących ambicji krytyka, który pisze w tym miejscu - jakby

${ }^{28}$ S. Barańczak, O pisaniu wierszy, w: Tablica z Macondo..., s. 239.

29 J. Kandziora, Ocalony w gmachu wiersza. O poezji Stanistawa Barańczaka, Warszawa 2007, s. 292.

30 A. Bielik-Robson, op.cit., s. 129.

${ }^{\text {I }}$ Źródłem tej metafory jest oczywiście myśl Martina Heideggera - zob. M. Heidegger, Bycie i czas, przeł. B. Baran, Warszawa 2004.

${ }^{22}$ Zwrócił na to uwagę Kandziora: „Scena w nowym mieszkaniu [...] - oto właściwie gotowy pomysł na wiersz, jaki mógłby się znaleźć w Cbirurgicznej precyzji”. J. Kandziora, op.cit., s. 293. 
właśnie z poczucia ludzkiej solidarności - w pierwszej osobie liczby mnogiej, w roli reprezentanta zbiorowości.

A jednak w żaden sposób nie da się interpretować omawianego eseju - ani całej twórczości autora Nieufnych $i$ zadufanych tylko przez pryzmat „nieufności” i „samotności”, choćby dlatego właśnie, że Barańczak formułuje wypowiedź we wspomnianej formie, podkreślając już na poziomie gramatycznym wspólnotowy wymiar doświadczenia. Okazuje się, że cała jego spójna teoria poezji i poety czyni z faktu, że świat stawia jednostkę w swoim „centrum”, raczej punkt wyjścia do walki o usensownienie tej pozornie absurdalnej sytuacji człowieka. Diagnoza autora Etyki i poetyki nie musi skutkować postawą rezygnacji, apatii, braku woli. W istocie $\mathrm{z}$ jego wywodów wyłania się - funkcjonujący wyraźnie w opozycji do „słabego” podmiotu z metafory mieszkalnej - obraz jednostki, która z różnymi skutkiem, ale jednak uparcie broni „przyrodzonego prawa do ludzkiej normalności, do ludzkiej normy". Mimo że krytyk nie precyzuje w tym eseju, jaką „normę” ma na myśli, to jednak - gdyby uwzględnić jego cały dorobek twórczy i życiowy - wiadomo, że buntował się on zawsze „w imię wartości jak najbardziej humanistycznych w rozumieniu klasycznej filozofii esencji - w imię wolności i prawdy" 33 , jak pisze Marcin Jaworski. Możliwości obrony tych elementarnych wartości tkwią między innymi w „komunikacyjnych sprawnościach" języka, które - odpowiednio wyzyskane - nie pozwalają przystać na „nihilizm nieufności”, kierują podmiot w przeciwną stronę: ku „etyce nieufności”.

Wyzyskać je może oczywiście tylko, czy też przede wszystkim, poeta $-\mathrm{z}$ tej perspektywy Barańczak rysuje jego obraz zdecydowanie czerpiąc z romantycznego paradygmatu ${ }^{34}$. Spróbujmy przyjrzeć się wizji mowy poetyckiej, tak jakby wyobrażenie to miało stanowić "standardy wszelkich poczynań językowych". Druga zasadnicza metafora w omawianym tekście otwiera więc zupełnie inną, konkurencyjną wobec poprzedniej, przestrzeń dla podmiotu jako takiego, ale też - równocześnie podmiotu każdej wypowiedzi językowej. Jest nią porównanie poety - od którego krytyk rozpoczyna swój szkic, wrzucając

33 M. Jaworski, Dekonstrukcja jezyyka, rekonstrukcja mowy, w: Rezersy nowoczesności. Klasycyzm i romantyzm w poezji oraz krytyce powojennej, Poznań 2009, s. 89.

34 Romantyzm to jedna z podstawowych tradycji literackich, w jakiej badacze sytuują twórczość Barańczaka od samego jej początku. Dariusz Pawelec właśnie przekonanie o mocy słowa, które jest czynem, uznaje za jedną z cech romantycznej świadomości bohatera wierszy autora Dziennika porannego zob. D. Pawelec, Poezja Stanisława Barańczaka. Reguły i konteksty, Katowice 1992, s. 121-135. 
czytelnika natychmiast $\mathrm{w}$ precyzyjnie przemyślany tok swojego wywodu - do „prostodusznego partnera w kabaretowym skeczu, w którym głównym komikiem - monologującym bez chwili odpoczynku, nie dającym sobie przerwać, przekrzykującym nas bez ceregieli - jest świat" ${ }^{35}$. Barańczak opisuje tę dialektykę:

Odezwania [...] partnera dialogu nie przyciągnęłyby, rzecz jasna, naszej uwagi, gdyby nie były częścią składową skeczu z rozgadanym światem w roli głównej [...]. Ale i, odwrotnie rzecz biorąc, nie potrafilibyśmy może dopatrzyć się sensu w ogłuszającym potoku wymowy szalonego clowna, gdyby nie zapytania i riposty jego partnera, które całej paplaninie nadają jaki-taki kształt i sens ${ }^{36}$.

Głęboka świadomość słabej kondycji człowieka spotyka się więc jednocześnie z oporem wobec świata. Barańczak od początku swojej działalności krytycznej konsekwentnie mówi o poezji w kategoriach protestu, sprzeciwu, wołania, wyzwania. Sedno jego odczytania twórczości Zbigniewa Herberta w Uciekinierze z Utopii - czyli teza, iż ,istotą tej poezji jest głęboki i zasadniczy paradoks: trzeźwe rozpoznanie sytuacji współczesnego człowieka stoi w elementarnej sprzeczności z dramatycznym gestem niezgody na tę sytuację" 37 - jest równocześnie sednem jego własnej teorii poezji i języka w ogóle. Przekucie wyjściowej sytuacji egzystencjalnego „wrzucenia w świat” w sytuację, która ma dla człowieka zrozumiały sens, staje się zasadniczym zadaniem poety jako dysponenta języka poetyckiego, posiadającego moc usensowniającą.

Właśnie w eseju O pisaniu wierszy znajdujemy najbardziej chyba wyraziste i zwięzłe wyjaśnienie znaczenia tak podkreślanej przez krytyka na każdym kroku nadorganizacji poetyckiej jednego $\mathrm{z}$ newralgicznych momentów zarówno teorii poezji, teorii przekładu poezji, jak i poezji własnej Barańczaka ${ }^{8}{ }^{8}$. Przyj-

35 Zauważmy, jak daleko Barańczak odchodzi tutaj od ironii - jednej z naczelnych kategorii, w których kontekście zwykle opisuje się jego twórczość. Poeta z krytycznej metafory dialoguje ze światem jak najbardziej serio.

$3^{6}$ S. Barańczak, O pisaniu wierszy, s. 238.

37 S. Barańczak, Uciekinier z Utopii. O poezji Zbigniewa Herberta, Wrocław 1994, s. 194.

$3^{8}$ Por. z opinią Jaworskiego na temat twórczości poetyckiej autora Dziennika porannego: „Krytyków i badaczy poezji Barańczaka niepokoił od początku nadmiar chwytów poetyckich. O zbłądzenie w kierunku popisowego efektu «sztuki dla sztuki» martwił się w połowie lat siedemdziesiątych Tadeusz $\mathrm{Ny}$ czek, a wobec «naprężonej poetyki» niektórych utworów Chirurgicznej precyzji dystansowała się w drugiej połowie lat dziewięćdziesiątych Anna Legeżyńska” (M. Jaworski, op.cit., s. 93-94). Zob. także retoryczne pytanie Andrzeja Sosnowskiego dotyczące praktyk translacyjnych Barańczaka: „Czy uznanie dla tak często demonstrowanej przez naszego thumacza umiejętności pracy pod 
rzyjmy się temu najlepszemu podsumowaniu wszystkich według krytyka zasadniczych cech poezji, które zapewniają jej uprzywilejowane miejsce wśród innych dyskursów:

To stąd te wszystkie rymy, rytmy, metafory, gry słów - to tylko rozmaite formy naginania bełkotu świata do jakiegoś znaczącego porządku, nadawania potokom jego chaotycznej wymowy jakiegoś kierunku i sensu. To po to dążenie do konkretu i zwięzłości aby przeciwstawić się wsysającej nas w lej nicości potędze pustych abstrakcji i statystycznych ogólników. To dlatego całe to mówienie w pierwszej osobie liczby pojedynczej i widzenie rzeczy w ściśle indywidualnej perspektywie - to po prostu sposób poezji na stawianie oporu światu, ilekroć chce on zepchnąć jednostkę ze sceny 39 .

Barańczak nie pozostawia więc wątpliwości, że poetyka organizacji i porządku ma dla niego silne uzasadnienie etyczne, wynika z egzystencjalnej potrzeby sensu, z potrzeby przeciwstawienia się „maniakalnemu wielogłosowemu majaczeniu” świata, który „jak wizjonerzy w niektórych sektach religijnych - mówi wieloma językami naraz" ${ }^{40}$. Czy wytyczne tego rodzaju stosować tylko do liryki? Odnoszę wrażenie, że nie. Można by tutaj zacytować Brodskiego (jego poezję i eseistykę Barańczak tłumaczył i omawiał), który w jednym ze swoich tekstów stwierdza: „poezja [...] nie tylko przedstawia doświadczenie ludzkie w najbardziej zwięzły, skondensowany sposób, lecz również ustanawia najwyższy standard wszelkich poczynań językowych - zwłaszcza na papierze" " ${ }^{1}$. Wydaje się, że tak właśnie ma się rzecz w przypadku eseistyki Barańczaka, którego działania na języku krytycznym - poniekąd wzorowane na operacjach dokonywanych w poezji - nie są obojętne dla warstwy dyskursywnej tekstu. Jak miałyby się więc jego refleksje do języka prozy eseistycznej i krytycznoliterackiej?

Zacznę od tego, że Barańczak z praktyk stylistycznych a więc $\mathrm{z}$ „form naginania bełkotu świata do jakiegoś znaczącego porządku” - wyciąga daleko idące wnioski etyczne. Gdy pisze:

pełnym obciążeniem rygorystycznej formy nie jest już zwykłym truizmem?” (A. Sosnowski, Frost, Larkin, Auden u Stanistawa Barańczaka, w: Najryzykowniej, Wrocław 2007, s. 206).

39 S. Barańczak, O pisaniu wierszy, s. 240.

$4^{\circ}$ Ibidem, s. 237.

${ }^{4}$ J. Brodski, Jak czytać książki, w: Pochwała nudy, przeł. A. Kołyszko, M. Kłobukowski, wybór, oprac. S. Barańczak, Kraków 1996, s. 82. Jak wiadomo, jego twórczość - zarówno poetycką, jak i eseistyczną - Barańczak tłumaczył i omawiał (por. chociażby S. Barańczak, Rłm i czas, w: Tablica z Macondo..., s. 132-137). 
„pośród szybko banalizującego się szaleństwa właśnie normalność może stać się objawieniem" ${ }^{22}$, to słowa te odnieść można również do języka - języka zarówno poezji, jak i eseistyki, a także innych gatunków literackich - i przekuć je w postulat organizacji oraz dyscypliny języka. Taki język może być odpowiedzią na ludzkie „zapotrzebowanie na sens”, stanowiąc wręcz swoisty wymóg moralny. Pozornie nieistotna „poetyckośc” - a więc organizacja wypowiedzi, spójność, kondensacja znaczeń (rozumiana jako właściwość nie tylko poezji, ale i potencjalnie każdej wypowiedzi, w tym też eseistycznej) - może być funkcją języka etyki. Głęboka wiara w język - niestojąca wcale w sprzeczności z postulatem „nieufności”, lecz dopełniająca go pozytywnym układem odniesienia - choć przyjmuje tak specyficzną dla Barańczaka postać - znajduje wiele punktów wspólnych $\mathrm{z}$ ideą "rządów języka” (the Government of the Tongue) Seamusa Heaneya. „Rządów języka” poetyckiego. Zacytujmy korespondującą z ideami eseju O pisaniu wierszy wypowiedź irlandzkiego poety, z którą bez wątpienia zgodziłby się Barańczak:

I tak jak w procesie swojego powstawania wiersz jest przykładem zgodności między impulsem a właściwym działaniem, tak w swoim trwaniu daje nam przeczucie upragnionej i niemałym kosztem zdobytej harmonii. W ten sposób osiągnięcie, jakim jest porządek sztuki, zostaje przeniesione także poza dzieło, chociaż związek dzieła $\mathrm{z}$ tym zewnętrznym porządkiem pozostaje raczej $\mathrm{w}$ sferze obietnicy niż zobowiązania [podkr. - H.T.] ${ }^{43}$.

Jaka nauka płynie z tychże rządów języka dla innych typów wypowiedzi? Czy można w ogóle szukać takiej harmonii, o jakiej pisze Heaney, poza poezją? Spróbuję teraz przyjrzeć się odrobinę bliżej retoryce eseju O pisaniu wierszy. Można zaryzykować stwierdzenie, że jest on swoistą językową realizacją poszukiwań równowagi w świecie - w świecie, w którym zgodnie z wykładnią Barańczaka jednostka jest rozdarta między sferą prywatną a publiczną, między potrzebą indywidualizmu a koniecznością zaangażowania, między poczuciem samotności a poczuciem solidarności.

$\mathrm{Z}$ tego, co do tej pory ustaliłam, wyłonił się już pewien niewyraźny obraz budowy dyskursu w eseju O pisaniu wierszy. Wspomniałam już wcześniej o zasadniczych metaforach, jakie w nim występują, i ich wzajemnym dopełnianiu się. Chciałabym

$4^{2}$ S. Barańczak, O pisaniu wierszy, s. 238.

43 S. Heaney, Rzadyjęzyka, w: Zawierzyć poezji, Kraków 1996, s. 157. 
również zwrócić uwagę na to, że każda metafora, jaką buduje Barańczak, jest więc zawsze głęboko przemyślanym chwytem, który nie ma ubarwić wypowiedzi, ale przynieść wyrazisty obraz, który nie zamąci sensu wypowiedzi, lecz go rozjaśni. Dlatego też jego chwyty językowe działają często jednocześnie jako całość i jako zbiór części, a Barańczak uwzględnia różne implikacje wybranych przez siebie tropów czy obrazów retorycznych. Jeśli rysuje on w pewnym miejscu eseju O pisaniu wierszy obraz człowieka będącego mieszkańcem świata domu, to nie będzie zaskoczeniem dla uważnego odbiorcy, gdy w innym fragmencie tekstu spotka się z konsekwencjami tej metafory - dzięki czemu wyłaniająca się z eseju wizja podmiotu wyda się konstruktem spójnym i przekonującym. Dzieje się to, gdy Barańczak kontynuuje i uściśla zarysowany wcześniej obraz, pisząc, że „poeta to lokator niezbyt logiczny: przyznaje z ociąganiem, że, owszem, powinien był przed podpisaniem umowy dokładniej zapoznać się z jej dodatkowymi klauzulami, zarazem jednak upiera się, że paragrafy swoją drogą, a właściciel nie ma prawa lokatorami poniewierać" ${ }^{4}$.

Barańczak okazuje się tutaj poniekąd uczniem George'a Orwella, który w eseju Polityka i język angielski kładł ogromny nacisk właśnie na funkcjonowanie metafor w języku i ubolewał nad faktem, że piszący „posługują się [...] metaforami, nie znając ich znaczenia”, „mieszają metafory zupełnie do siebie niepasujące" 45 . Warto też przywołać w tym miejscu wypowiedź Marka Skwary, który w szkicu O polskiej retoryce po 1945 roku tak ustosunkowuje się do interesującego nas problemu: „Wyjaśniającą funkcję metafor w nauce trudno przecenić, ale muszą to być metafory dobre i wiarygodne, które powodują całkowicie nowe rozumienie jakiegoś zjawiska, a nie są tylko elementami zgrabnie zestawionych opozycji” ${ }^{46}$. Tak też ma się rzecz u Barańczaka w eseju $O$ pisaniu wierszy, gdzie również wyjściowe porównanie poety do partnera skeczu stanowi operację od początku do końca przemyślaną. To właśnie „ukryta logika metafory” - na którą często powołuje się i w innych szkicach - prowadzi autora do nieuchronnej konkluzji, wedle której poezja staje się zawsze „ofiarą szyderstwa”. Warto zauważyć, że choć jest ona „pesymistyczna”, to jednak w planie retorycznym domknię-

44 S. Barańczak, O pisaniu wierszy, s. 239.

45 G. Orwell, Polityka i język angielski, w: Jak mi się podoba. Eseje, felietony, listy, wybór, wstęp P. Śpiewak, przeł. A. Husarska, M. Szuster, B. Zborski, Warszawa 2002, s. 272.

${ }_{46}$ M. Skwara, Opolskiej retorycepo 1945 roku, w: Retoryka, red. M. Skwara, Gdańsk 2008, s. 11. 
cie wypowiedzi, zatoczenie przez nią idealnego koła, powrót do początkowej metafory i nowe jej rozumienie raczej potwierdzają jaśniejsze zakończenie: „choć poeta nie ma w tej roli ostatniego słowa - ma przynajmniej szansę cokolwiek powiedzieć. Zawsze to więcej niż rola niemego statysty" ${ }^{47}$.

Zrekapitulujmy. Barańczaka refleksja o poezji wykracza poza zwyczajne diagnozy literaturoznawcze, nieustannie - nieraz zaskakująco - korespondując z diagnozami współczesnych filozofów, prowokując do pytań o nowoczesną podmiotowość ${ }^{8}$. I to zarówno w jego teoretycznych rozważaniach na temat istoty poezji, jak i w recenzjach poszczególnych tomików poetyckich, esejach traktujących o konkretnych dziełach literackich. Mogliśmy więc zaobserwować, jak szerokie jest działanie „paradoksu tożsamości" w krytyce Barańczaka i że w pewnym sensie streszcza ono w sobie podstawowe idee jego twórczości - a nawet i życiowej działalności - które explicite formułuje on na przestrzeni wielu różnych tekstów, także tych $\mathrm{z}$ węższego zakresu teorii poezji. Wydaje się, że autor Etyki i poetyki mógłby podpisać się pod słowami Charlesa Taylora, według którego „wciąż jeszcze możemy postrzegać siebie jako część większego porządku, wobec którego mamy określone obowiązki” ${ }^{49}$. Tego rodzaju przekonanie będzie milcząco towarzyszyć Barańczakowi jako eseiście, krytykowi literackiemu, recenzentowi, stanowiąc fundament jego wizji podmiotu. Wyróżniona przeze mnie figura paradoksu okazała się więc tropem najlepiej wyrażającym uogólnioną prawdę na temat rozdartej tożsamości człowieka i otaczającej go rzeczywistości, wobec której musi jakoś się ustosunkować także językowo. Na niestabilnym bowiem gruncie - taki daje teza o zasadniczej paradoksalności świata i egzystencji człowieka - Barańczak buduje jednak spójny system etyki języka, a duża część jego wysiłku pisarskiego zmierza ku temu, by język jego wypowiedzi eseistycznej mógł sprostać wyzwaniu, jakim jest opis ambiwalentnej rzeczywistości i sytuacji człowieka współczesnego.

47 S. Barańczak, O pisaniu wierszy, s. 241.

${ }^{8}$ Ze znanych mi opracowań twórczości Barańczaka dwa na pewno umieszczają ją w rozległej perspektywie modernizmu. Mam na myśli rozdział z książki Arenta van Nieukerkena Ironiczny konceptyzm. Nowoczesna polska poezja metafizyczna (Kraków 1998, s. 283-355) i szkic Marcina Jaworskiego Dekonstrukcja jezzyka, rekonstrukcja mowy (s. 80-97).

49 Cyt. za: A. Bielik-Robson, op.cit., s. 281. 


\section{HANNA TRUBICKA}

\section{Between loneliness and solidarity. Around the problems of subjectivity in later literary critical texts by Stanisław Barańczak}

The issue of subjectivity is raised in the theoretical and critical works on poetry authored by Barańczak, so to speak, marginally. Despite the fact, the issue of identity seems to constitute their core subject and is organically related to other relevant key threads such as, primarily, the issue of the "ethics of distrust". Interestingly enough, the ambivalence of the situation of an individual, - placed somewhere between the individualistic and the community perspective - which is emphasized by Stanisław Barańczak by making rhetoric figure of paradox particularly privileged - is also expressed in the language in which the critic describes the problem. His observations come down ultimately to one thing: a consistent search in different writers for a confirmation of the assumption on the paradoxical nature and bi-dimensionality of human existence.

Key words: Polish poetry in the first half of the 20th century, history of literary criticism, subjectivity, Stanisław Barańczak.

HANNA TRUBICKA - absolwentka Międzywydziałowych Indywidualnych Studiów Humanistycznych UMK, doktorantka w Instytucie Filologii Polskiej UAM. Publikowała m.in. w „Pamiętniku Literackim”, dwutygodniku „artPAPIER”, „Pograniczach”. Jest tegoroczną laureatką wyróżnienia w Konkursie im. J.J. Lipskiego za pracę magisterską poświęconą krytyce literackiej Stanisława Barańczaka. 
